\title{
Magdi H. Yacoub: Celebrating the AATS Scientific Achievement Award
}

\author{
Thoralf M. Sundt, MD \\ From the Division of Cardiac Surgery, Massachusetts General Hospital and Edward D. Churchill Professor of Sur- \\ gery, Harvard Medical School, Boston, Mass. \\ Disclosures: Author has nothing to disclose with regard to commercial support. \\ Received for publication Oct 23, 2017; accepted for publication Oct 30, 2017. \\ Address for reprints: Thoralf M. Sundt, MD, Massachusetts General Hospital, 55 Fruit St, Boston, MA 02114 \\ (E-mail: tsundt@mgh.harvard.edu). \\ J Thorac Cardiovasc Surg 2018;155:850-2 \\ 0022-5223/\$36.00 \\ Copyright (c) 2017 by The American Association for Thoracic Surgery \\ https://doi.org/10.1016/j.jtcvs.2017.10.089
}

It is difficult to know where to begin in summarizing the contributions made to our profession-and beyond-by an individual whose name is so widely familiar to members of all subspecialties of the cardiothoracic surgical community. It is even more intimidating, given the immensely high regard in which I and so many of my closest friends hold the man for whom the simple moniker "Prof" can only mean one individual. Therefore, I will take the easy way out.

Magdi Habib Yacoub was born in Bilbeis, Al Sharqia, Egypt, the son of a general surgeon practicing in locations as needed in the service of his country's Ministry of Health. Magdi was a precocious youth, starting formal schooling at the age of 3, skipping a grade, and matriculating to medical school at the age of 15 . Enthralled by science, his career trajectory toward medicine in general, and surgery in particular, was undoubtedly inspired by his father's example and that of 2 uncles who were also surgeons. Perhaps most profound, however, was his witness to the impact of the tragic death of his father's dear sister in childbirth in her early 20 s secondary to rheumatic mitral stenosis just as surgical approaches to treat the condition were being pioneered in England and elsewhere. Magdi's father felt deeply that her death would have been preventable had the latest surgical techniques been available to her. The experience propelled him in an obvious way toward the then-emerging field of cardiac surgery, while in a more subtle way it foreshadowed another life-long mission to improve access to care for the underserved.

It must not have been an accident that Yacoub sought out training under the early giants in the treatment of valvular heart disease in the United Kingdom, including Lord Brock and O. S. Tubbs. His commitment to this subspecialty has been lifelong, with many contributions to the literature throughout his career on the topic. Beyond their purely clinical inspiration, these role models and others, including most notably Norman Barrett, demonstrated to an impressionable youth the importance of being a "thinking surgeon"; a surgeon scientist's career was launched.

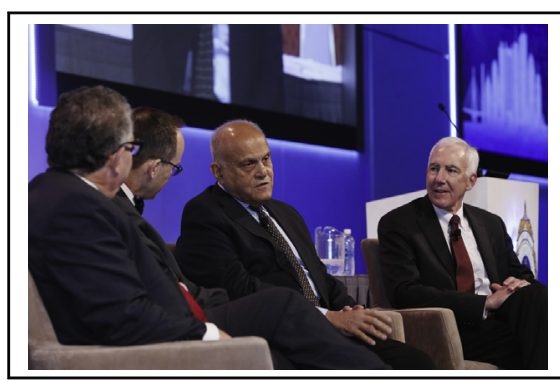

Prof at The American Association for Thoracic Surgery Centennial meeting with 3 students on stage and an audience of hundreds.

Central Message

Magdi Habib Yacoub: An inspirational role model for us all.

Yacoub's initial staff appointment was to Harefield Hospital, a small, specialty-focused hospital in a rural setting established outside London during World War I to treat injured AnZac (Australia and New Zealand) soldiers and rebuilt in the 1930s as a tuberculosis sanatorium. Armed with an insatiable curiosity, massive intellect, truly brilliant technical surgical talents, and an incredible capacity for work, "M.Y." entered the institution thoughtfully respectful of those individuals already in practice there. His aim was not to displace others but instead to advance the institution. His energy and infectious enthusiasm transformed the modest hospital into the most active cardiothoracic surgical transplant program on the planet. There, he and his team pioneered such innovations as heterotopic heart transplantation $^{1}$ and the domino heart-lung/heart transplant procedure. ${ }^{2}$ Their interest in lung transplantation led to the development of techniques for bronchial artery revascularization as well.

Some surgeons, if they are fortunate, make one such significant contribution or if particularly talented make several related ones in a single subspecialty area. Not so for Yacoub. Remarkably, at the same time that new ground was being broken in transplantation, "M.Y." was establishing an active practice in congenital heart surgery at both Harefield and at the Brompton, where he worked with the cardiologist Rosemary Radley-Smith to develop the arterial switch operation virtually simultaneously with Adib Jantene. Theirs was the second successful case of the same, ${ }^{4}$ performed within weeks of Jatene's. ${ }^{5}$ Prof has 
made equally impressive contributions in the treatment of valvular heart disease, developing the first technique for valve-sparing root replacement, now commonly referred to as "remodeling." ${ }^{, 6} \mathrm{He}$ also pioneered the now-standard technique for homograft aortic valve replacement, the freestanding root operation, ${ }^{7}$ and has conducted one of the few randomized trials in valvular heart disease in comparing long-term outcomes of patients undergoing the pulmonary autograft operation versus homograft aortic valve replacement. ${ }^{8}$

Add to these accomplishments a generous spirit eager to share knowledge with students and visitors from all over the globe, and it is no surprise that pilgrimage to Harefield became a pivotal event in the career development of many of today's leaders in cardiothoracic surgery. Late at night—or was it early in the morning-Prof would host what amounted to a cardiothoracic salon, with international visitors debating current controversies and weighing in on new laboratory findings reported in the journals Nature or Science. As a clinical surgeon he was a role model, emphasizing simplicity and efficiency in motion, and creativity in problem solving in the context of a deep appreciation for anatomy and functional physiology. But it was his manner as a human being, listening respectfully and attentively to the ideas of everyone, from the most junior to most senior colleagues equally, that garnered for him universally high regard-near reverence-from his students. I hasten to add that this is not to say that he was reluctant to disagree with any of us as well! But we always felt important and that our views were valued.

These accomplishments would be enough to place Prof among the undisputed giants of our field. But there is another facet of the man that sets him apart and is in fact the reason that this particular award-for Scientific Achievement-is so appropriate.

Prof is a committed scientist with an insatiable appetite for discovery. In fact, routinely taking clinical questions to the research team and investigative discoveries to the bedside throughout his career, I would argue that M.Y. was a translational scientist well before the term was coined. Clearly the spark arose in childhood, but perhaps most remarkably he has managed to nurture that excitement and enthusiasm within himself and inspire it in those around him throughout his illustrious career. Embodying a scientific approach to clinical practice, he did more on his arrival at Harefield than build a remarkable clinical service; one of his first goals was to establish a substantive laboratory presence. And build it he did. Today, the Heart Science Centre on the campus of Harefield Hospital houses research laboratories under the auspices of the Royal Brompton and Harefield National Health Service (NHS) Foundation Trust as well as the Magdi Yacoub Institute, including 4 independent research groups and up to 25 scientists and $\mathrm{PhD}$ students working on projects investigating aspects of heart valve biology and tissue engineering, cardiac biophysics, myocyte contractility, cardiac remodeling, and pulmonary hypertension. Many of the projects are performed in collaboration with Yacoub's research team at the Aswan Heart Centre in Egypt.

There is no barrier-physical or intellectual-between the laboratories and the clinic for Yacoub. At Harfield, he would retire to his office in the Heart Sciences Centre between cases and immerse himself in the activities there just as research students would routinely seek him out in the clinical space to review an abstract (usually due within hours) or the most recent laboratory findings. The result is a body of work including more than 1000 citations in the peer-reviewed literature - to all of which he has contributed substantively. Recent publications span the waterfront, from valve interstitial and endothelial cell biology ${ }^{9-11}$ to valve tissue engineering, ${ }^{12}$ from nanoparticles ${ }^{13,14}$ to ventricular assist devices and other approaches to the recovery of the failing heart ${ }^{15,16}$ and from genetics, ${ }^{17,18}$ to the science of health care delivery. ${ }^{19-21}$ I have it on good authority that Prof would rather be considered a scientist-surgeon than the converse!

For these scientific accomplishments, Prof has gained the respect of scientists of the first order. In 1999, he was elected to membership in the Royal Society. Founded in 1660 , the Royal Society is the oldest scientific academy in continuous existence. It counts among its members Newton, Darwin, Faraday, and Hawking. It was the Royal Society that published Newton's Principia in 1687 and it was before this body that Benjamin Franklin demonstrated the electrical nature of lightning.

Most recently, Yacoub received the Lister Medal from the Royal College of Surgeons. It is an award that has been granted only 27 times since its establishment in 1924 and is considered the most distinguished award in surgery in Great Britain and Ireland. The selection for the award is made by a committee, with members appointed by the Royal Society, the Royal College of Surgeons of England, the Royal College of Surgeons in Ireland, the University of Edinburgh, the University of Glasgow, and the Society of Academic and Research Surgery. As such, he joins Evarts Graham, Lord Brock, John Kirklin, and Norman Shumway as cardiothoracic surgical recipients. In addition to these, he has honorary memberships that are quite literally too numerous to count.

For most, these contributions would be enough, but Prof has also demonstrated a lifelong commitment to serving the underserved. He practiced within the structure of the NHS for his entire career and served as a consultant to the Ministry of Health to ensure adequate access to cardiac surgery throughout the United Kingdom. In that capacity, he worked to enhance communication between the government officials and clinicians and was ultimately made "Special Envoy" for the NHS. He is currently 
focused on several important international effortsparticularly on the treatment of congenital heart disease. The Magdi Yacoub Foundation established the Aswan Heart Centre in 2009 to provide free medical services for those in need. Yacoub founded the Chain of Hope Charity in 1996 and is dedicated to providing care to children with heart disease in Egypt, Ethiopia, Jamaica, Mozambique, Uganda, Jordan, and El Salvador through partnerships with multiple hospitals, including The Harley Street Clinic, Great Ormond Street Hospital for Children NHS Trust, Royal Brompton and Harefield Hospital NHS Trust, Guy's and St Thomas' NHS Trust, Narayana Hrudayalaya Health City, Bangalore, Leipzig Heart Centre, and Aswan Heart Centre, Egypt.

As a result of these efforts nationally and internationally, Yacoub was made Knight Bachelor by Queen Elizabeth II in 1992, the only physician in that class. Even more impressively, in 2014 he received the Order of Merit, an honor bestowed personally by the monarch limited to 24 living persons. Lord Darzi of Denham is the only other physician among that group.

Now, how to close? Knowing the man as I think I do, he would not want us simply to be impressed; he would want us to be inspired. Because in my view, more than anything else, that is how he has accomplished so much. He expresses an optimism and open-mindedness that attracts talented individuals and supports their creativity. It is his irrepressible "can-do" attitude that is the hallmark of his activity. And it is something that we can all emulate, regardless of our inherent technical or intellectual attributes. He will not hear "that's impossible" or "there's no way that can ever be done." Instead, he asks "how can we do that?" and "what happens if we do this?" We should all do more of the same.

The author thanks Drs Shelley Rahman Haley and Adrian Chester for help and advice in composing this tribute.

\section{References}

1. Ridley PD, Khaghani A, Musumeci F, Favaloro R, Akl ES, Banner NR, et al. Heterotopic heart transplantation and recipient heart operation in ischemic heart disease. Ann Thorac Surg. 1992;54:333-7.

2. Yacoub MH, Banner NR, Khaghani A, Fitzgerald M, Madden B, Tsang V, et al. Heart-lung transplantation for cystic fibrosis and subsequent domino heart transplantation. J Heart Transplant. 1990;9:459-66; discussion 466-7.
3. Daly RC, Tadjkarimi S, Khaghani A, Banner NR, Yacoub MH. Successful double-lung transplantation with direct bronchial artery revascularization. Ann Thorac Surg. 1993;56:885-92.

4. Yacoub MH, Radley-Smith R, Hilton CJ. Anatomical correction of complete transposition of the great arteries and ventricular septal defect in infancy. $\mathrm{Br}$ Med J. 1976;1:1112-4.

5. Jatene AD, Fontes VF, Paulista PP, de Souza LC, Neger F, Galantier M, et al. Successful anatomic correction of transposition of the great vessels. A preliminary report. Arq Bras Cardiol. 1975;28:461-4

6. Sarsam MA, Yacoub M. Remodeling of the aortic valve anulus. J Thorac Cardiovasc Surg. 1993;105:435-8.

7. Gula G, Ahmed M, Thompson R, Radley-Smith R, Yacoub M. Combined homograft replacement of the aortic valve and root with reimplantation of the coronary arteries (abstr). Circulation. 1976;53(suppl 2):150.

8. El-Hamamsy I, Eryigit Z, Stevens LM, Sarang Z, George R, Clark L, et al. Longterm outcomes after autograft versus homograft aortic root replacement in adults with aortic valve disease: a randomised controlled trial. Lancet. 2010;376: 524-31.

9. Salhiyyah K, Sarathchandra P, Latif N, Yacoub MH, Chester AH. Hypoxia-mediated regulation of the secretory properties of mitral valve interstitial cells. Am J Physiol Heart Circ Physiol. 2017;313:H14-23.

10. Mongkoldhumrongkul N, Latif N, Yacoub MH, Chester AH. Effect of sidespecific valvular shear stress on the content of extracellular matrix in aortic valves. Cardiovasc Eng Technol. October 5, 2016 [Epub ahead of print].

11. Mongkoldhumrongkul N, Yacoub MH, Chester AH. Valve endothelial cells—not just any old endothelial cells. Curr Vasc Pharmacol. 2016;14:146-54.

12. Marei I, Chester A, Carubelli I, Prodromakis T, Trantidou T, Yacoub MH. Assessment of parylene $\mathrm{C}$ thin films for heart valve tissue engineering. Tissue Eng Part A. 2015;21:2504-14.

13. El-Sherbiny IM, Elbaz NM, Sedki M, Elgammal A, Yacoub MH. Magnetic nanoparticles-based drug and gene delivery systems for the treatment of pulmonary diseases. Nanomedicine (Lond). 2017;12:387-402.

14. Mohamed NA, Ahmetaj-Shala B, Duluc L, Mackenzie LS, Kirkby NS, Reed DM. A new NO-releasing nanoformulation for the treatment of pulmonary arterial hypertension. J Cardiovasc Transl Res. 2016;9:162-4.

15. Jakovljevic DG, Yacoub MH, Schueler S, MacGowan GA, Velicki L, Seferovic PM, et al. Left ventricular assist device as a bridge to recovery for patients with advanced heart failure. J Am Coll Cardiol. 2017;69:1924-33.

16. Felkin LE, Walsh R, Ware JS, Yacoub MH, Birks EJ, Barton PJ, et al. Recovery of cardiac function in cardiomyopathy caused by titin truncation. JAMA Cardiol. 2016;1:234-5.

17. Krishnamoorthy N, Gajendrarao P, Olivotto I, Yacoub M. Impact of diseasecausing mutations on inter-domain interactions in cMyBP-C: a steered molecular dynamics study. J Biomol Struct Dyn. 2017;35:1916-22.

18. Sanoudou D, Kolokathis F, Arvanitis D, Al-Shafai K, Krishnamoorthy N, Buchan RJ, et al. Genetic modifiers to the PLN L39X mutation in a patient with DCM and sustained ventricular tachycardia? Glob Cardiol Sci Pract. 2015;2015:29.

19. Gemechu T, Mahmoud H, Parry EH, Phillips DI, Yacoub MH. Community-based prevalence study of rheumatic heart disease in rural Ethiopia. Eur J Prev Cardiol. 2017;24:717-23.

20. Balbaa A, ElGuindy A, Pericak D, Yacoub MH, Schwalm JD. An evaluation of secondary prophylaxis for rheumatic heart disease in rural Egypt. Glob Cardiol Sci Pract. 2015;2015:40.

21. Dokainish H, Teo K, Zhu J, Roy A, AlHabib KF, ElSayed A, et al; INTER-CHF Investigators. Heart failure in Africa, Asia, the Middle East and South America: the INTER-CHF study. Int J Cardiol. 2016;204:133-41. 